\title{
Attracting skilled immigrants: \\ An overview of recent policy developments in advanced countries ${ }^{1}$
}

\author{
Giovanni Facchini \\ School of Economics, University of Nottingham \\ Elisabetta Lodigiani \\ Ca' Foscari, University of Venice
}

\begin{abstract}
In this paper we review the policies put in place by the main Western destination countries to attract highly skilled migrants. Two main systems can be identified. On the one hand, employer-driven schemes typically call for the migrant to meet a set of minimum skill requirements and to have a job offer before a work visa can be issued. On the other, employee driven schemes typically do not require a job offer, and instead select the migrant based on a set of characteristics chosen by the policy maker. Employer driven schemes are the dominant policy tool in the sample of countries we consider in the analysis, and only Australia, Canada and New Zealand have made employee-driven schemes the mainstay of their skill selective immigration policy. The preliminary evidence we review suggests that the latter are more effective in increasing the skill level of the immigrant population, and casts doubts on the usefulness of new initiatives like the EU blue card that are still based on an employer driven system.
\end{abstract}

JEL: F 22, J61

\footnotetext{
${ }^{1}$ The authors gratefully acknowledge financial support provided by the Miller Center at the University of Virginia.
} 
"Skilled labor migration into Europe boosts our competitiveness and therefore our economic growth. It also helps tackle demographic problems resulting from our ageing population. This is particularly the case for highly skilled labour. With today's proposal for an EU Blue Card we send a clear signal: highly skilled immigrants are welcome in the EU!" Jose Manuel Barroso, $2007^{2}$

\section{Introduction}

Selecting migrants according to the skills needed in the labour market is an increasingly widespread practice among developed countries - even if the recognition of degrees earned in foreign universities and/or the portability of pension and health care benefits are still important unresolved issues. ${ }^{3}$

Skill selective policies have a long history in traditional destination countries and in particular in Australia, Canada and New Zealand, and, to a lesser extent, in the United States. ${ }^{4}$ Conversely, most traditional European receiving countries have either focused on recruiting from abroad manual/unskilled workers, or have not pursued skill-selective immigration policies at all for decades. Increasing concerns that Europe may be on the losing end of the contest for talents and, as a consequence, may see its long term economic growth prospects decline, has resulted in policy reforms both at the levels of the EU and of its member states, with the explicit goal of improving the skill profile of foreign workers arriving in the region.

In this paper we provide an overview of the skill selective immigration policies adopted in the main Western destination countries and of the major shifts which have been recently observed in these policies. We proceed in the following steps. Section 2 provides an overview of recent developments in the channels of entry of foreigner migrants. In Section 3 we outline the main approaches which have been implemented to select highly skilled immigrants. We turn then in Section 4 to describe the main features of the policies implemented in countries which have a long tradition in selecting highly skilled immigrants, i.e. Australia, Canada, New Zealand and the US. In Section 5 we take instead a closer look at the recent policy developments in the European Union, where important efforts have been undertaken to coordinate policy at the supra-national level, with the explicit goal of making the region a more attractive destination for highly skilled foreign workers. We will in particular discuss the recent introduction of the "Blue card" initiative, and analyze the parallel changes that have been introduced in the policies of some of the main destination countries in the EU. In Section 6 we will put our analysis in a global perspective, discussing some of the evidence that emerges from a recent survey carried out by the United Nations on government's policies towards skilled immigration. Section 7 concludes.

\footnotetext{
2“"European Commission launches new push for 'Blue Card”" Der Spiegel November 7, 2007, p. 1-2..

${ }^{3}$ For an interesting example of how complex procedures to recognize foreign degrees might result in significant barriers to the migration of medical professionals, see Glied and Sarkar (2009). For an overview of the portability of pension and health care benefits, see Holzmann et al. (2005).

${ }^{4}$ Interestingly, skill-selective policies have been introduced mainly following the elimination of explicitly discriminatory policies based on the immigrant's country of origin in the early to mid sixties.
} 


\section{An overview of the main channels of entry}

International statistics allow us to identify three broad channels of entry for international migrants. Individuals can relocate abroad to work, to join/move together with family members or to escape persecution in their country of origin. As labour mobility is free within the European Union, the OECD data collected for EU member countries contain also information on the stock of foreign nationals coming from other EU members. The same holds for Australia and New Zealand, two countries which have a free labour mobility agreement. Table 1 provides a broad overview of the patterns of settlement in 2010 for the countries we have included in our study.

A few striking stylized facts emerge. First, family reunification appears to be the main channel of entry for foreign nationals. On average, 44 percent of the migrants residing in the OECD have been admitted either to be rejoined to family members already living in the destination country (family), or as tied movers (i.e. accompanying family of workers). The importance of the family channel would increase further if we were to focus our discussion on individuals that cannot benefit from free mobility within the EU (the share would increase to 55 percent of the total). Work is the second most important channel of entry, representing 21 percent of the total admissions, whereas admissions under the humanitarian channel represent only about 7 percent of the total. Importantly, in 2010 about 20 percent of the foreign residents in OECD countries were admitted under the EU free movement arrangement, suggesting that intra-European migration is becoming more important.

The average figures conceal substantial heterogeneity among individual countries. In each of the traditional non European destinations (Australia, Canada, New Zealand and the United States) family reunification covers more than one half of the total arrivals: the figure is a stunning 74 percent for the United States, sixty percent for Australia, 59 percent for Canada and 58 percent for New Zealand. In countries that have received large immigration flows only recently - like Spain or Italy - the relevance of the family reunification channel is much smaller, as it covers respectively only 19 and 28 percent of the total number of inflows. At the same time, for more recent destinations the labour market channel plays a much more important role: 40 percent of the foreign nationals admitted in Italy in 2010 came to the country to work, and in the case of Spain the corresponding figure was 30 percent. At the same time only 6 percent of the permanent inflows in the United States in that year was represented by individual who came to work, and even for countries like Australia, Canada and New Zealand, that have made skilled migration the capstone of their immigration policy, the labour market channel does not cover more than 27 percent of the admissions.

Thus, while assessing the role that skill-selective immigration policies can play in shaping the composition of the foreign born population, it is always important to keep in mind that regulating immigration is a complex task and that basic human rights considerations do constrain the set of policies that can be actually implemented in Western democracies. 
Table 1: Permanent inflows into selected OECD countries, by category of entry, 2010.

\begin{tabular}{lcccccc}
\hline & Work & $\begin{array}{c}\text { Free } \\
\text { movements }\end{array}$ & $\begin{array}{c}\text { Accompanying } \\
\text { family of } \\
\text { workers }\end{array}$ & Family & Humanitarian & Other \\
\hline Canada & 0.27 & - & 0.39 & 0.21 & 0.12 & 0.00 \\
Australia & 0.22 & 0.12 & 0.30 & 0.28 & 0.07 & 0.01 \\
New Zealand & 0.25 & 0.09 & 0.32 & 0.28 & 0.06 & - \\
United States & 0.06 & - & 0.08 & 0.66 & 0.13 & 0.06 \\
France & 0.12 & 0.30 & - & 0.43 & 0.05 & 0.10 \\
United Kingdom & 0.33 & 0.17 & 0.15 & 0.12 & 0.01 & 0.22 \\
Germany & 0.09 & 0.60 & - & 0.25 & 0.05 & 0.01 \\
Denmark & 0.20 & 0.51 & 0.06 & 0.12 & 0.05 & 0.06 \\
The Netherlands & 0.11 & 0.57 & - & 0.22 & 0.10 & - \\
Italy & 0.40 & 0.28 & 0.01 & 0.27 & 0.01 & 0.01 \\
Spain & 0.30 & 0.50 & - & 0.19 & 0.00 & 0.01 \\
EU (excl. free mov.) & 0.39 & - & 0.06 & 0.38 & 0.06 & 0.11 \\
\hline OECD total & 0.21 & 0.20 & 0.08 & 0.36 & 0.07 & 0.07 \\
\hline \hline Source: OECD International Migration Database & & & &
\end{tabular}

\section{Classifying skill-selective immigration policies}

Countries that have in place specific systems to attract skilled workers employ a wide array of policy instruments, which can be broadly classified as "immigrant driven" or "employer driven" (Chaloff and Lemaitre, 2009). Under the former, an immigrant is admitted in the country without necessarily having a job offer and is selected on the basis of a set of desirable attributes. Under the latter, an employer has to make a job offer in order to grant admission to a highly skilled foreign worker.

"Immigrant driven" systems typically use a "point assessment" to determine the desirability of a foreign national. This type of framework has first been introduced in Canada in 1967, followed by Australia in 1989 and New Zealand in 1991. More recently, the UK has experimented a similar framework, and point based systems have been introduced also in Denmark in 2008, and to a lesser extent in the Netherlands in 2009.

Point systems are used to select individuals on the basis of characteristics that make them "desirable". The selection involves the identification of a "pass rate" and, typically, point systems attribute a substantial weight to five criteria: occupation; work experience; education; destination country language proficiency and age. A second set of criteria, which can be included in point systems, is also relevant. This includes: employer nomination/job offer; prior work in the destination country; education obtained in the destination country; settlement stipulations; presence of close relatives and prior earnings.

\footnotetext{
5 An interesting proposal for the construction of an "optimal" point-based system has been recently put forward by McHale and Rogers (2009).
} 
Broadly speaking, we can distinguish two different economic models that underpin the attribution of "points" in the first set of criteria. On the one hand, we have a short-term stance, in which emphasis is posed on the need to fill gaps in the destination country's labour market. In such a model, the applicant's recent occupation and work experience are particularly highly rewarded. On the other hand, we can identify a long-term perspective, which is inspired by an earnings or human capital economic model. In this context, education, age and official language proficiency are instead the main focus.

In "employer driven" skilled immigration systems - like the US H1B visa system or the current UK Tier 2 system - employers are the key players. They offer the foreign national a job, sponsor his/her the application and typically carry out a "labour market" test. The purpose of the test is to establish that the vacancy for which an immigrant is requested cannot be filled by a local worker, and the stringency of the labour market test varies substantially across countries.

\section{Skill-selective immigration policies in traditional immigration countries}

It is useful to briefly review the salient features of the different systems to get a better sense of how they work in practice, keeping in mind that many actual migration systems blend facets of both employer and immigrant driven frameworks.

Table 2: The Canadian point system

\begin{tabular}{|c|c|c|c|c|c|c|}
\hline & 1967 & 1978 & 1986 & 1996 & 2009 & 2013 \\
\hline \multicolumn{7}{|c|}{ Maximum number of points } \\
\hline Experience & - & 8 & 8 & 9 & 21 & 15 \\
\hline $\begin{array}{l}\text { Specific vocational } \\
\text { preparation }\end{array}$ & 10 & 15 & 15 & - & & - \\
\hline Occupational demand & 15 & 15 & 10 & - & & - \\
\hline Labour market balance & - & - & - & 10 & & \\
\hline Education & 20 & 12 & 12 & 21 & 25 & 25 \\
\hline Language proficiency & 10 & 10 & 15 & 21 & 24 & 28 \\
\hline Age & 10 & 10 & 10 & 13 & 10 & 12 \\
\hline $\begin{array}{l}\text { Arranged employment } \\
\text { or designated } \\
\text { occupation }\end{array}$ & 10 & 10 & 10 & 4 & 10 & 10 \\
\hline $\begin{array}{l}\text { Personal } \\
\text { suitability/Adaptability }\end{array}$ & 15 & 10 & 10 & 17 & 10 & 10 \\
\hline Levels adjustment factor & - & - & 10 & - & & - \\
\hline Realtive & 5 & 5 & - & 5 & & - \\
\hline Destination & 5 & 5 & - & - & & - \\
\hline Total & 100 & 100 & 100 & 100 & 100 & 100 \\
\hline Pass mark & 50 & 50 & 70 & $*$ & 67 & 67 \\
\hline
\end{tabular}

Sources: Green and Green (1999) and Citizenship and Immigration Canada. "Pass mark" denotes the number of points which are required for admission. 


\section{Canada}

The point system for the "independent" (or economic) class was introduced in Canada in 1967 and, since then, it has been used as the core criterion to determine which individuals will gain access to the country as skilled migrants. The economic class was expanded to include a "business" class of immigrants in 1986, but its numeric importance has been limited and has not exceeded a few percentage points of the total. In 2007, approximately 98,000 individuals, or 41 per cent of the total, have been admitted under the skilled worker program as either principal applicants or spouses and dependants (CIC 2008), down from an average of around 50 per cent for the period 2000-2006.

The working of the system has changed substantially over time, with new criteria being introduced and others being removed. The "pass rate" has also varied over time, ranging from 50 points (out of a total of 100) in 1967, to 70 in 1986. The system's evolution is illustrated in Table 2. In the first twenty years since its introduction, the focus was on the occupational needs of the economy at any given point in time. Since the 1990s the focus has changed, and now Canada implements a migration policy towards the skilled, which is no longer based on a "gap filling" strategy, but rather on an earnings/human capital perspective.

The main goal of the new policy is to favour the immigration of individuals that are more likely to adapt successfully, and thus assimilate faster. This is continually reflected in the most recent changes introduced in the point system. Language proficiency is now the most important single factor in the selection criteria. Age at entry receives now more weight, whereas foreign work experience has been downgraded, as research has shown that this is only a weak predictor of success in the Canadian labour market. Educational Credential are now assessed on the basis of the value of educational credentials in Canada and no longer on the basis of those of the home country. Overall, the new policy aims at selecting younger skilled workers, proficient in official languages, who can integrate more rapidly and successfully in the Canadian labour market.

In many ways, the Canadian experience with the point system is particularly interesting, as it represents the evolution from a short-run migration model, focused on contingent labour market shortages, to a long-run framework where the focus is on adaptability of the immigrants to the destination country.

\section{Australia}

Most immigrants to Australia today enter under one of three categories: skilled workers, family reunification or humanitarian. In 2010, 22 per cent was made up by skilled workers, whereas in 1985 their share was only 10 per cent (Linacre 2007).

This important change is the result of a series of initiatives introduced throughout the 1980s, which culminated in the "points test" formally introduced in 1989. Under this regime, every year the Minister for Immigration not only sets the overall target for permanent settlers to be admitted in the country, but it also fixes the numbers of individuals to be allowed in for family reunification and as skilled workers. For instance, according to the 2013-14 Migration Program for permanent migrants, up to 190,000 individuals can be admitted, and a large majority of the quota is allocated to skilled migrants $(67.7 \%)$, with family reunification 
permits representing instead $32 \%$ of the total. ${ }^{6}$ Whenever a category requires a "points test", the government also announces the "pass mark".

Skilled immigrants can enter through four main channels. A "general skilled migration" scheme is in place for those who do not have an employer sponsoring them; an "employer nominated" scheme is instead intended for those who have a sponsor. Successful entrepreneurs can be admitted through a "business skills migration" scheme, whereas exceptionally talented individuals can have access to the "distinguished talent" framework. Focusing on the first two categories, under the "general skilled migration" scheme, individuals can apply provided that their occupation is listed in the Skilled Occupation List (SOL) and the relevant assessing authority has certified that they possess the required qualifications. Under the Employer Nominated Scheme, an employer must have nominated the immigrant to fill a position in an occupation that appears in the Consolidated Sponsored Occupation List (CSOL). ${ }^{7}$ The lists are updated at high frequency (annually), based on labour market conditions. As of July 2013, the SOL comprises 188 high value occupations, while the CSOL includes 649 occupations. In recent years, as part of the Employer Sponsored Program, initiatives were also introduced to encourage migration to specific areas of the country to address local skill shortages (Regional Sponsored Migration Scheme (RSMS)). Currently (since July 2013), regional employer sponsored visas have the highest processing priority, followed by applicants under the Employer Nomination Scheme (ENS), and under the points-tested skilled migration scheme. ${ }^{8}$

As of July 1, 2012, a new model for the selection of immigrants for the "general skilled migration" scheme has been introduced, which requires the perspective migrant to submit an expression of interest (EOI) online. Qualified applicants are then invited to lodge a visa application. Importantly, reaching the "pass mark" in the point system does not immediately guarantee an invitation to move to Australia, as the highest scoring applicants will be invited first, until the quota is filled.

Table 3 provides a snapshot of the point distribution in place as of 2013, together with the "pass mark" for the general skilled immigration scheme. Differently from the Canadian point system, the Australian one is largely driven by the short-term needs of the local labour market. Moreover, in the Australian system the employer route is becoming more important. For instance, in 2010-11, the number of skilled migrants admitted through the employer nominated scheme was almost two times as big as the one admitted through the employee driven scheme (Phillips and Spicks, 2012).

\footnotetext{
${ }^{6}$ See http://www.immi.gov.au/media/statistics/statistical-info/visa-grants/migrant.htm.

${ }^{7} \mathrm{http} / / /$ www.immi.gov.au/skilled/general-skilled-migration/pdf/csol.pdf.

${ }^{8} \mathrm{http}: / /$ www.immi.gov.au/media/fact-sheets/24apriority_skilled.htm.
} 
Table 3: The Australian skilled migration system, 2013

\begin{tabular}{lc} 
& $\begin{array}{c}\text { Maximum } \\
\text { number of } \\
\text { points }\end{array}$ \\
\hline Age & 30 \\
English Language Ability & 20 \\
Skilled Employment: & 20 \\
Educational Qualification & 20 \\
Australian study requirements & 5 \\
Other factors: & \\
Credentialed community language qualifications & 5 \\
Study in regional Australia or a low population growth metropolitan area & 5 \\
(excluding distance education) & 5 \\
Partner skill qualifications & 5 \\
Professional Year in Australia for at least 12 months in the four years & \\
before the day you were invited & 5 \\
Nomination/sponsorship: & 5 \\
Nomination by state or territory government & \\
Nomination by state or territory government or sponsorship by an eligible & \\
family member, to reside and work in a specified/designated area & 60 \\
\hline Pass Mark
\end{tabular}

Source: Australian Government (http://www.immi.gov.au/skills/skillselect). Pass mark" denotes the number of points which are required for admission

\section{New Zealand}

Up until the early seventies migration policy in New Zealand was strongly biased in favour of UK and Irish nationals, who enjoyed practically unrestricted access to the country, and against Asian immigrants. After the first oil shock a series of changes were introduced that put an end to assisted migration and restricted immigration also from the traditional origins. In particular, the concept that entry was to be granted on the basis of the existing demand for skills and qualifications was introduced in the legislation, even if the details concerning the application of this principle remained rather vague.

The Immigration Policy Review of 1986 represents a turning point, calling for admission procedures that were intended not to discriminate on the basis of the country of origin and/or ethnicity. This policy was formalized in the 1987 Immigration Act, which distinguished four different channels of entry: employment, business, family and humanitarian. Under the employment grouping, any person who had received a job offer for employment in one of the jobs listed under the Occupational Priority List was eligible for a residence permit, regardless of race or nationality (Winkelmann 1999). ${ }^{9}$

\footnotetext{
${ }^{9}$ Before 1987, immigration was subject to both an occupational priority list (OPL) and to a preferred country list. An OPL existed since the mid-1960s. After 1976, the employment from non-traditional countries was possible under certain specific conditions (Winkelmann, 1999).
} 
Table 4: The New Zealand point system

\begin{tabular}{lcccc}
\hline \hline & 1994 & 2001 & 2009 & 2013 \\
\hline Skilled employment (current & 3 & 5 & 60 & 60 \\
NZ/offer NZ) & & & 35 & 50 \\
SE Bonus points & 10 & 10 & 30 & 30 \\
Relevant work experience & & 40 & 45 \\
RWE Bonus points & 15 & 12 & 55 & 60 \\
Qualifications & & 9 & 30 & 65 \\
Q Bonus points & 10 & 10 & 10 & 10 \\
Family ties/settlement factors & 43 & 46 & 30 & 30 \\
Age & $20-31$ & $24-25$ & 100 & 350 \\
Total & & & 100 \\
\hline Pass mark & & & \\
\hline Sources: OECD (2003b) and New Zealand Immigration Service (http://www.immigration.govt.nz/). “Pass \\
mark" denotes the number of points which are required for admission.
\end{tabular}

The Immigration Amendment Act of 1991 explicitly introduced a "point system" for the general skill category of immigrants, replacing the occupational priority list, and abandoning the requirement of a job offer (Winkelmann 1999). Between 1991 and 2003, the system has undergone only minor changes (Table 4). ${ }^{10}$ The main innovation in the early phase of the program - introduced in 1995 - has been a change in focus from qualifications as a sign of employability to a job offer, together with the introduction of additional points for settlement factors. A major change was introduced instead in 2003. As a result, a much greater emphasis is now posed on short-term occupational background than on general educational qualification. Importantly, initial applications ("expression of interest" in the current jargon) meeting the minimum "pass rate" will not automatically entitle the applicant to admission in the country, but rather they lead to the inclusion into a "pool" in which they will remain for up to 6 months. Those ranking at the top of the pool (in terms of points obtained) will then be "invited to apply" for residence, at a biweekly frequency. Thus, the New Zealand system has evolved into a model where entry is granted on the basis of very short-term labour market considerations, and little attention is paid to the long-term consequences of immigration policy.

\section{The United States}

The United States remain one of the main destinations for highly skilled immigrants, even if the country has not put in place a point system to select prospective foreign workers based on their qualifications. Currently, the main instrument to admit skilled workers is represented by the H1B visa category, which was introduced in the 1990 Immigration Act, and targets workers to be employed in a "specialty occupation", defined as requiring theoretical and practical application of a body of highly specialized knowledge in a field. ${ }^{11}$ Under this

\footnotetext{
${ }^{10}$ The General Category was replaced by the General Skill Category in 1995 (NZ Parliamentary Library Research paper, 2008).

${ }^{11}$ A second important potential channel of entry for skilled workers is represented by the F1 visa category, which is used by foreign students acquiring a higher education in the US. This visa category allows the students also to complete a post-graduation period of optional practical training.
} 
program, 65,000 visas are issued annually, ${ }^{12}$ and the minimum skill requirement is a bachelor's degree. Visa requests need to be sponsored by a prospective employer, and a Labour Condition Application needs to be submitted to ensure that the foreign workers do not displace or adversely affect wages or working conditions in the US.

The H1B visa does not fall under the "immigrant visa" category, i.e. it does not automatically result in the conferral of a permanent resident status. At the same time, it is one of the few visa categories allowing a worker to apply for permanent residency. The H1B visa category is a typical example of an "employer driven" system. Beyond the H1B visa, there are other visa programs for highly skilled workers, reserved to intra-company transferees (L1), internationally recognized athletes and entertainers $(\mathrm{P})$, workers of extraordinary ability $(\mathrm{O})$ etc. (Facchini, Mayda and Mishra, 2011).

Table 5 provides an overview of the number of non-immigrants visas which have been issued, on average, between 2006-2011. Two different broad categories can be distinguished: "work and related visas" and "other admissions." As it is immediately apparent, the "other admission category", which includes temporary visitors, official representatives, transitional family members and students plus their spouses/children, represents approximately 85 percent of the non-immigrant visas issued over the period. "Work and related visas account instead for approximately 15 percent of the total. More specifically out of the 944,315 work and related visas granted every year, 318,164 were issued to "Temporary workers", a group that includes visa categories such as: H1-B (reserved to workers of distinguished merit and ability), H1A \& H1C (registered nurses and nurses in shortage area), H2A (workers in agricultural services), H2B (workers in other services), H3 (trainees) and H4 (spouses and children of temporary workers). The other work and related visas were assigned, for example, to "Intra-company transferees and spouses/children" (L1, L2) "workers with extraordinary ability in the sciences, arts, education, business, or athletics" (O1, O2), "internationally recognized athletes or entertainers" (P1, P2, P3), "religious workers" (R1) and "exchange visitors" (J1). Interestingly H1B visas - which represent the main channel of entry for skilled workers in the United States - account for only about one third of the total number of visas issued to temporary workers, and only for about 14 percent of the total of work and related visas. In fact some observers like Beach et al. (2007) have suggested that the absence of a specifically designed point based system might have played a key role in explaining the comparatively lower skill level of immigrants in the US than in immigration countries with point-based systems like Canada or Australia.

\footnotetext{
${ }^{12}$ The actual number has changed several times at the end of the nineties. For more information on this, see Congressional Research Service (2006).
} 
Table 5: Number and types of non-immigrant visa issuances, 2006-11

\begin{tabular}{|c|c|c|}
\hline Type of temporary admission & Visa Category & Average 2006-11 \\
\hline Work and related visas & & 944,315 \\
\hline Exchange visitors and spouses/children & $\mathrm{J} 1, \mathrm{~J} 2$ & 361,142 \\
\hline Workers with extraordinary ability & $\mathrm{O} 1, \mathrm{O} 2$ & 12,902 \\
\hline Internationally recognized athletes or entertainers & $\mathrm{P} 1, \mathrm{P} 2, \mathrm{P} 3$ & 33,771 \\
\hline Cultural Exchange and Religious Workers & Q1, Q2 R1 & 8,244 \\
\hline Treaty traders/investors and their children & $\mathrm{E}$ & 38,693 \\
\hline Spouses/children of certain foreign workers & $\mathrm{O} 3, \mathrm{P} 4, \mathrm{Q} 3, \mathrm{R} 2, \mathrm{I}$ & 20,618 \\
\hline NAFTA Professionals and spouses/children & TN, TD & 7,261 \\
\hline Intra-company transferees and spouses/children & $\mathrm{L} 1, \mathrm{~L} 2$ & 143,522 \\
\hline Temporary workers of which: & & 318,164 \\
\hline Workers of distinguished merit and ability & H1B & 128,289 \\
\hline Registered nurses and nurses in shortage area & $\mathrm{H} 1 \mathrm{~A}, \mathrm{H} 1 \mathrm{C}$ & 72 \\
\hline Workers in agricultural services & $\mathrm{H} 2 \mathrm{~A}$ & 53,960 \\
\hline Workers in other services & $\mathrm{H} 2 \mathrm{~B}$ & 61,373 \\
\hline Trainees & H3 & 2,477 \\
\hline Spouses and children of temporary workers & $\mathrm{H} 4$ & 71,992 \\
\hline Other admissions & & $5,492,179$ \\
\hline Temporary Visitors & $\begin{array}{c}\mathrm{B} 1, \mathrm{~B} 2, \mathrm{~B} 1 / \mathrm{B} 2, \\
\mathrm{~B} 1 / \mathrm{B} 2 / \mathrm{BCC}\end{array}$ & $4,611,791$ \\
\hline Official representatives and transitional family & $\mathrm{A}, \mathrm{G}, \mathrm{K}$ & 186,011 \\
\hline Students and spouses/children & $\mathrm{F} 1, \mathrm{~F} 2, \mathrm{M} 1, \mathrm{M} 2$ & 379,082 \\
\hline Other non work visas & & 315,295 \\
\hline Total non immigrant visa issuances & & $6,436,494$ \\
\hline
\end{tabular}

Source: Data are based on the 'Report of the Visa Office' (http://travel.state.gov). Notice that aliens issued a visa do not necessarily enter the United States in the year of issuance.

\section{Skill-selective immigration policies in the European Union}

The immigration policies of the EU have been traditionally characterised by a fundamental dualism. On the one hand, internal labour mobility is one of the core provisions of the Common Market and, hence subject to EU level jurisdiction, while the immigration of thirdcountry nationals remains largely in the national policy domain of each member state, even if recent efforts have been made to promote the introduction of a set of common rules and requirements. The free movement of workers within the Common Market is by definition not skill-selective. However, the EU is trying to actively pursue the mobility of high-skilled individuals within the Common Market. This goal has inspired for instance the recent efforts to harmonize education policies and in particular the introduction of harmonized study programmes under the umbrella of the "Bologna process", and the mutual recognition of university degrees. Still, there are important obstacles to the access to liberal professions which remains regulated at the national level. Limited pension portability across countries is another important hindering factor for labour mobility.

Regarding third-country nationals, most EU member states have mainly recruited manual workers from abroad during the 1960s and the early 1970s, and then pursued restrictive immigration policies in the aftermath of the first oil price shock of 1973 (Zimmermann, 
1995). Concerns that the EU may lose out in the global contest for highly skilled workers and that labour shortages will become widespread as a result of demographic changes have meanwhile triggered several new policy initiatives at the EU level. At the 1999 Tampere (Finland) meeting of the European Council, the EU leaders introduced some important elements for a common EU immigration policy, to fulfil the broad objective of attracting highly skilled individuals from abroad. As a result, the EU has started to play a more active role in immigration policies vis-à-vis third-country citizens, through a series of initiatives of the European Commission, namely the Green Paper on an EU approach to managed immigration (EC, 2004) and the Policy Plan on Legal Migration (EC 2005), which outline a strategy for attracting particularly skilled and highly skilled migrants. For the selection of highly skilled immigrants, two initiatives are particularly relevant: two directives of the European Council regulate the admission of students (European Council 2004) and researchers (European Council, 2005) from third-countries. Both directives have eased the entry of third-country nationals as students and researchers to the EU, and simplified their mobility across EU member states once they have been admitted by one member country.

\subsection{The EU Blue Card initiative}

An important EU wide initiative to promote the inflow of foreign skilled workers is the European Council Directive on "the conditions of entry and residence of third-country nationals for the purpose of highly qualified employment", which has been adopted on May 25, 2009 (Directive 2009/50/EC) and bounds all EU member states, except Denmark, the United Kingdom and Ireland. The rationale behind this initiative was the perceived limited success of national programs aimed at attracting skilled foreign workers, and the basic idea was that a broader, Europe-wide, set of labour market opportunities would instead give the continent an edge in the global competition for talents. As a result, a key provision of the Blue Card is the enhanced access it provides to the EU labour markets.

The initiative is a typical employer driven scheme, that is limited to a common definition of the criteria to qualify for admission under the highly skilled migration program (the existence of a work contract, professional qualifications, and a salary above a minimum level set at the national level), without prejudice to more advantageous conditions provided by national laws. The validity of the initial permit varies substantially across issuing countries (from a minimum of one year and up to four). "Blue card holders" face restrictions on their ability to change employment in the first two years of their permanence in the granting country, and they can find employment only in the receiving country's labour market for the first 18 months after arrival. Importantly, more freedom of movement is contemplated after this period, including the possibility for the migrant to gain access to a second member country's labour market. Still, the procedure is rather cumbersome, as to be allowed to work in the second country the applicant needs to obtain a new blue card issued by the local government, and might be prevented from working while waiting for a decision (Art. 18). After five years of continuous and legal residence within the territory of the European Community the Blue Card holder can apply for EU long term resident status, provided that he has held continuous and legal residence in the country where the application is lodged in the last two years.

Directive 2009/50/EC was to be implemented by June 2011, but delays have seen most countries introducing national legislation to incorporate the Blue Card provisions only in 2012. Importantly, while the Blue Card initiative has lied out some common principles that will inspire domestic legislation on skilled migration, ample margins of discretion are retained by each member country, and in particular no coordination is envisaged as far as the 
actual number of migrants to be admitted (Article 6). Moreover, the Blue Card initiative does not prevent individual countries to continue to retain separate additional schemes to admit highly skilled workers. Importantly though, these national schemes will not grant a right of residence in other EU member countries.

\subsection{Skill-selective immigration policies in a group of EU member countries}

Although the competencies of the EU in the area of immigration policy have steadily increased over the past fifteen years, the core decisions continue to fall in the domain of national governments. Thus, to assess the actual selectivity of immigration policy in Europe it is important to look at national level initiatives. In this section we will review the policy stance of a group of selected countries, which represent the broad variety of experiences of the region with immigration. We start by considering three large historical destination countries - France, the United Kingdom and Germany, who have experienced large inflows of foreign workers since the early post WWII period. We then turn to examine the experience of two smaller destination countries, in which immigration has been particularly salient issue in the last few years (Denmark and The Netherlands). Last we will explore how two Mediterranean countries, which have only recently become important immigrant destinations, have approached policy selection. In several instances, a policy to attract skilled immigrants has been introduced starting at the end of the nineties. The focus is typically on attracting skilled workers for a finite period of time, even though provisions are typically introduced to make the acquisition of permanent residence easier for skilled workers than for other categories of migrants.

\section{France}

France has a very long history of immigration, and bilateral agreements with source countries were signed already at the beginning of the twentieth century to handle the labour shortages created by the rapid industrialization process. ${ }^{13}$ After the Second World War, and during the boom years of the "trente glorieuse" (1945-1975), France once again actively recruited workers from other European countries, such as Italy, Portugal, Spain, Belgium, Germany, Poland and Russia, as well as from colonies/former colonies, like Algeria or Tunisia. This period, characterized by a relatively open migration policy, came to an end with the economic crises that followed the first oil shock. Like in other European immigration countries, labour immigration came to a halt, and migrant workers were incentivated to return to their origin countries. This policy had limited effects though, and through family reunification foreign citizens, especially from former colonies, continued to enter the country.

During the eigthies immigration became the subject of much political debate, and the controversial "Pasqua laws" of 1986 and 1994 pursued explicitly the goal of "zero immigration". To this end a series of restrictive measures were implemented, ranging from making family reunification more difficult, to the introduction of limits to the ability to find a job in France for foreign graduates of French universities. These laws saw widespread opposition from the civil society, and the following socialist government of prime minister

\footnotetext{
${ }^{13}$ For instance, labour recruitment agreements were signed with Italy (1904, 1906, 1919), Belgium (1906), Poland (1906) and Czechoslovakia (1920).
} 
Jospin introduced less restrictive measures. For instance, the "Chevenement" law of 1998 favoured family reunification and established clearer criteria for the granting of refugee status. The "Guigou" law of 1998 esatablished a ius soli for children of migrants born in France.

From 2000 onwards, a series of changes in immigration legislation reflected a new policy stance, in which family reunification and asylum lost importance as channels of entry, and more emphasis was instead given to labour migration. In particular, the 2006 and 2007 immigration and integration laws contained provisions to explicitly encourage high-skilled migration and facilitate foreign students's stay. Besides employer driven work visas (two tracks area available for individuals with long and short term contracts), the 2006 legislation introduces a "skills and talents" visa (carte de sèjour "compétences et talents"), which is granted for a period of three years to qualified workers with a "professional project" that should make a significant or lasting contribution to France's economic development or to its intellectual, scientific, cultural, humanitarian or athletic standing. In principle, this visa does not require a job contract, but admission is nevertheless conditioned on the presentation of a concrete project, that must be approved by the relevant French immigration authority. Interestingly, all these visas are not subject to an explicit numeric restriction (quota). However, in practice only 345 and 365 "cartes competence et talents" were issued respectevely in 2009 and 2010 (Sopemi, 2011).

Recent legislation has also introduced fiscal incentives for foreign professionals coming to France from January 2004. These include a five year tax exemption for bonuses directly related to their assignment in France, and tax deductions for social security payments made by the expatriates in their home countries. A deduction is also be available for pension and health care payments made outside France (Profit et al., 2008).

The move twoards a more skill selective immigration policy has continued also in the most recent years. In 2011, France has introduced legislation to implement the EU Blue Card initiative. To qualify under this scheme the individual needs to have an employment contract for one year or more and a monthly salary amounting to at least 1.5 times the average gross salary taken as a reference and fixed annually by the Minister for Immigration ( $€ 52725$ gross per year in 2013). Furthermore, he/she needs to have completed at least a three-year bachelor degree or have proof of at least five years of professional experience at a level comparable to the one for which he/she will be working in France.

\section{United Kingdom}

After the Second World War, the United Kingdom experienced a large influx of migrants, ${ }^{14}$ especially from former colonies, which made it unnecessary to introduce a formal "guest workers" program, which has instead been a mainstay of migration policy in many Northern European countries during the reconstruction period. This was possible because the British Nationality Act of 1948 granted residents of UK colonies British citizenship, which allowed them the right to enter and work in the UK. These individuals were followed by their families in the 1960s and 1970s.

\footnotetext{
${ }^{14}$ In particular, between 1948 and 1962, approximately 500,000 new Commonwealth immigrants entered the United Kingdom (Hansen, 1999).
} 
The large inflow of immigrants during the fifties raised much concern and public discontent. As a result, a series of new measures was gradually introduced to make it more difficult for citizens of the British Commonwealth to move to the United Kingdom, starting with the 1962 Commonwealth Immigrants Bill, which ended the open door policy. The subsequent 1971 Immigration Act made it explicit that the UK was to be a country of zero net migration; furthermore, in the shadow of the US civil rights movement, it focused attention on the integration of existing migrants (Sommerville et al. 2009).

In the late eighties and throughout the nineties, an important feature of immigration to the United Kingdom was the large inflow of asylum seekers and refugees, and there was much debate in the country on whether these were not simply economic migrants in disguise. With the coming to power of the labour government in 1997, and the booming economy of the late nineties, the focus in the policy debate on immigration changed and an explicit commitment to economic migration was made. As a result, at the beginning of the new century, a broad policy overhaul was introduced involving on the one hand the tightening up of the requirements to qualify for asylum, and on the other, the introduction of a program targeting highly qualified individuals, i.e. the Highly Skilled Migrant Program which was launched in 2002. The latter was a point based system, which allowed a foreigner which satisfied a minimum points requirement to enter the country, even in the absence of a formal job offer.

This system has been reformed in 2008, when UK immigration policy was reorganized and a five-tier program was introduced. Under this new scheme, the Tier 1 and Tier 2 categories were reserved for skilled migrants. Under Tier 1, highly skilled foreign workers were allowed to apply for an entry permit, without the need of an existing job offer. The Tier 2 scheme was instead reserved to medium and highly skilled workers, but importantly, to be admitted under this program the third country nationals had to have already received a job offer.

The financial crisis of 2008 and the subsequent recession saw migration take the front stage of the political debate during the 2010 elections, and the Conservative party made the introduction of more restrictive policies part of its platform, with the explicit goal of reducing net migration to the UK below 100,000 individuals per year. The result was a more stringent scheme which was put into place in 2011, making it much more difficult even for highly skilled non-EU nationals to gain employment in the country. The Tier 1 program is the UK points based system and continues to allow foreign workers to be admitted even in the absence of a formal job offer, but the entry requirements have been made substantially stricter, and only truly "exceptional" foreigners are considered under this system. ${ }^{15}$ Depending on the admission category, strict numerical limitations might exist, but many observers have lamented the complicated process that needs to be followed to apply for these visas, which has left the quotas for several categories unfilled.

The Tier 2 category allows instead UK employers to hire third country nationals to fill particular jobs, and requires the existence of a job offer prior to application. Four subcategories have been identified, i.e. General, Intra Company Transfer, Sportsperson, Minister of Religion. For the fiscal year 2013 a total of 20700 visas can be issued under the General subcategory for workers earning less than 152,100 pounds. On the other hand, there is no cap for workers earning more than 152,100 pounds.

\footnotetext{
${ }^{15}$ Five subcategories have been identified: Exceptional talents (world leaders or individual with the potential to be world leaders in their fields); Entrepreneurs; Investors, General and Graduate Entrepreneurs (i.e. individuals that after graduation from a UK Higher Education Institution want to develop an existing viable business activity). The General category is now closed, while the first and the latter are subject to a quota of respectively 1000 and 2000 individuals per year.
} 
Recent data show that like in the Tier 1 case, also in the Tier 2 category number of visas issued has fallen substantially below the limit set by the quota (MAC 2012). This is likely to be the result of weak demand in the UK labour market, but might also be a signal of the complexity of the procedure companies need to follow in order to sponsor a visa under this program.

\section{Germany}

After the Second World War, like the United Kingdom and other Northern European countries, Germany experienced rapid growth that led to labour shortages, which were addresses by favouring on the one hand the immigration of ethnic Germans from Eastern Europe, and on the other through the establishment of a guest worker program, which resulted in the conclusion of a series of bilateral recruitment agreements. ${ }^{16}$ Following the first oil price shock in 1973 Germany stopped active recruitment policies. As a result, family reunification, humanitarian immigration and the immigration of ethnic Germans (the socalled "Spätaussiedler") became the main channels of entry.

Against the background of low skill levels in the immigrant population in Germany and of an increasing shortage of highly skilled labour, the Schröder government began to redefine immigration policies in the late 1990's. An important initiative was the introduction, in August 2000, of the so called "Regulation on Work Permits for Highly Qualified Foreign Labourers in Information and Communication Technology (IT/ArGV)“, also known as the "Green Card" initiative, which was meant to be a response to the shortage of information and communication technology specialists. To qualify for this type of visa ${ }^{17}$ the individual offered a job needed to meet a minimum skill requirement (a university or technical college degree) or his ability in this field needed to be recognized through a guaranteed gross annual salary of at least $€ 51,000$. The Green Card could also be obtained by international ICT students, allowing them to sign a labour contract in Germany directly following the completion of their studies. Importantly, the regulation also allowed Green Card holders to change jobs. The views on the effectiveness of this program are mixed. On the one hand, the original quota of 20000 visas was never fully subscribed. Existing estimates suggest that between 2000 and 2004, 17,111 "Green Cards" were actually issued (Constant and Tien, 2011), ${ }^{18}$ highlighting a broad lack of demand for this type of visas. On the other, these permits gave small and medium enterprises access to much needed foreign skills, whereas larger firms mainly took advantage of exisiting intracompany transfer programs to meet their staffing requirements.

The system was overhauled with the comprehensive immigration act of 2005 . Four channels of entry are identified in the new legislation, namely employment, education, family reunification and asylum/refugee seeking. As with the "Green Card" program, one of the main objectives of the new legislation is to attract highly skilled workers, and two groups have been targeted in particular: The first one comprises scientists and teaching personnel with excellent qualifications (i.e. university professors), outstanding sportsmen and artists. The second one refers instead to managers and specialists whose income is at least twice the ceiling of health insurance in Germany, i.e. it is above $€ 85,000$ p.a. as of 2008 , even though

\footnotetext{
${ }^{16}$ Agreements were signed in 1955 with Italy; in 1960 with Spain and Greece; in 1961 with Turkey, in 1964 with Portugal and in 1968 with the former Yugoslavia.

${ }^{17}$ The German green card, differently from the US omonimous program, was a temporary work permit which allowed the foreign worker to be employed in the country for up to five years. It also allowed the worker to bring his family with him.

${ }^{18}$ See also http://focus-migration.hwwi.de/index.php?id=1198\&L=1.
} 
the 2009 amendment of the immigration act reduced this ceiling to $€ 65,000 .{ }^{19}$ Both groups are entitled to permanent residence permits. Moreover, a residence permit was to be granted to individuals which are self-employed if they invest $€ 500,000$ and employ at least five persons (this threshold was reduced to $€ 250,000$ in 2009).

In quantitative terms, once again the evidence suggests that this reform did not manage to reach its goals. Only 466 residence permits have been granted for the two groups of highly skilled individuals in 2007, and only 115 of those have been granted to new arrivals. It is not likely that the 2009 reform changed the picture substantially, since the $€ 65,000$ income ceiling is still well above the average income level of individuals with a university degree, particularly in the age groups below 40.

A renewed effort to make the country an attractive destination for highly skilled immigrants is represented by the implementation, in August 2012, of the EU's Blue Card Directive. As a result, the EU Blue Card has become the only residence permit for highly skilled workers, and it is granted for a period of four years. The requirements to obtain a visa have been substantially simplified, compared to the previous legislation. In particular, the minimum income threshold has been reduced to $€ 46,400$, and this threshold has been further lowered to $€ 36,192$ for the so-called shortage occupations (scientists, mathematicians, engineers, doctors and IT- skilled workers). EU Blue Card holder can apply for permanent resident status after three years of residence (reduced to two if they can demonstrate good German language skills). While this less demanding set of requirements should make the country more attractive to foreign skilled workers, it is too early to carry out a quantitative assessment of whether the reception of the EU Blue Card has been a success.

\section{Denmark}

Like several Northern European destination countries, Denmark experienced rapid growth during the sixties and dealt with emerging labour market shortages by implementing a guest worker program. As a result, a substantial inflow of low skilled foreign workers took place during this period, with the main origin countries being Turkey, Pakistan and the former Yugoslavia.

Following the 1973 oil shock, this program came to a halt, but foreign workers already in the country were allowed to stay and bring their families to Denmark. At the same time, starting in the eighties and following the ratification of a series of international conventions, asylum seekers and refugees became a more important feature of migration in Denmark. Concerns about the low skill profile of migrants in the country and about possible abuses of the asylum/refugee protection schemes led the government to introduce in the late nineties a series of measures to tighten entry and integration requirements.

\footnotetext{
${ }^{19}$ Now the salary must at least correspond to the income threshold to the pension insurance scheme. In 2012, the income the treshold to the pension insurance scheme was at 67,200 Euro/year in Western Germany and at 57,600 Euro in Eastern Germany (Laubenthal, 2012).
} 
Table 6: The Danish Green Card, 2013

\begin{tabular}{|c|c|}
\hline & Maximum number of points \\
\hline Educational Level & 105 \\
\hline Degree & $\begin{array}{l}\text { As a minimum have the equivalent of a Danish } \\
\text { bachelor degree. } 80 \text { for } P h D\end{array}$ \\
\hline & Tор 400: 5 \\
\hline Bonus points if graduated from an internationally & Top 200: 10 \\
\hline recognized university & Top 100: 15 \\
\hline Bonus points if qualified in a field where Denmark & \\
\hline $\begin{array}{l}\text { is currently experiencing a shortage of qualified } \\
\text { professionals }\end{array}$ & 10 \\
\hline Language skills & 30 \\
\hline Work experience & 15 \\
\hline Adaptability & 15 \\
\hline Age & 15 \\
\hline General skilled immigration pass mark & 100 \\
\hline
\end{tabular}

At the same time, policies aimed at promoting the immigration of highly skilled foreign workers were introduced. In 2002 a job-card initiative came into existence to facilitate the recruitment of individuals whose professional qualifications were in short supply (Liebig, 2007). Since then a richer set of selective policies were introduced, involving both employerand employee- driven schemes. Several employer driven schemes are now in place, not only for individuals with particular skills (e.g., the so called "Positive List"), but also for indivudals who have been offered a highly paid job ${ }^{20}$ ("Pay Limit Scheme") etc. Importantly, in 2008 a Green Card initiative was introduced. This is a point based system aimed at attracting highly qualified foreigners from outside the EU/EEA. Under this initiative, it is possible to receive a residence permit for the purpose of seeking work, and subsequently working, in Denmark. This permit is initially granted for three years and can be renewed. In order to be qualified for it, an individual must obtain at least 100 points, and Table 6 illustrates its working. Besides offering special visa programs for highly skilled workers a special tax scheme has also been introduced, which allows foreign employees to pay a significantly lower tax rate $(26 \%)$ while working in Denmark for a period of up to five years.

\section{The Netherlands}

In the aftermath of the Second World War, the Netherlands saw half a million Dutch citizens leave the country, to look for employment in the USA, Canada, and Australia (National Contact Point, 2005). Starting from the mid sixties, however, this trend was reverted and the country has become the destination of growing immigrant flows. Much of the workers arriving in the country through the seventies and the eighties originated in former Dutch colonies - Indonesia, Suriname etc. At the same time, during the 60's the Netherlands started

\footnotetext{
${ }^{20}$ Currently set at have a gross annual pay of no less than DKK 375,000. http://www.nyidanmark.dk/enus/coming_to_dk/work/pay-limit-scheme.htm
} 
to recruit "guest-workers" for low-skilled jobs from Southern Europe, Yugoslavia, Turkey and Morocco.

As in the case of Germany, guest workers programs came to an end after the first oil crisis of 1973, but guest workers already in the country were allowed to stay and bring their families. The inflows due to family reunification peaked during the eighties and the nineties. A second important group of migrants that arrived in the Netherlands in the nineties were asylum seekers, mainly originating in countries like Afghanistan, Iran, Iraq, the former Yugoslavia and Somalia. The peak in the new arrivals of foreign migrants was reached in 2001, and was followed by a substantial decline in inflows, due both to tighter labour market conditions, as well as the introduction of stricter requirements for the granting of asylum and for family reunification.

In particular, the Aliens Act of 2000, was explicitly aimed at reducing low-skilled migration, and stricter rules were devised both for family reunification and asylum. The same line was pursued also in the 2006 Civic Integration Abroad Act, which requires migrants who want to come to the Netherlands to live with their partners to pass a civic integration test abroad on language and Dutch culture. ${ }^{21}$

At the same time, new measures were introduced to promote the immigration of highly skilled foreign workers. The 2004 Highly Skilled Migrant Scheme identifies "knowledge migrants" based on a job offer which meets a minimum income threshold. ${ }^{22}$ Under this scheme, foreign workers do not need a separate temporary work permit, but only a residence permit that it is granted for a maximum of five years. Approval times are very short, ranging between two and four weeks. After five years of legal residence knowledge migrants can apply for a permanent residence permit or consider naturalization.

Since December 2007, foreign students from outside the EU/EEA that graduate in the Netherlands do not need to leave immediately the country, but they can instead apply for the "orientation year for graduates seeking employment" This scheme allows bachelor's or master's students to have a one year search period for a job, immediately after graduation.

In January 2009, in addition to the previous program for foreign graduates of Dutch institutions, a new admission scheme has been introduced for highly educated migrants. This legislation allows recent foreign graduates, who have completed their studies in the last three years, to come to the Netherlands to look for a job as a knowledge migrant or to start an innovative company. The system grants points based on different criteria, and Table 7 provides a broad overview. The eligibility threshold is 35 points, and once this has been met, the highly skilled foreigner is granted a one year permit, which cannot be extended.

\footnotetext{
21 Some individuals are exempted from the civil integration test. This applies for instance to US, Australian, Canadian, Japanese, New Zealand or South Korean citizens.

${ }^{22}$ As of 1 January 2012: "A highly skilled migrant is a migrant who comes to the Netherlands to be employed, and has a gross annual income of at least $€ 51.239$, or $€ 37.575$ if he/she is under thirty, or for persons who have graduated in the Netherlands $€ 26.931$. This income requirement does not apply if the employee performs scientific research or is a doctor in training to become a specialist. " (http://english.ind.nl/nieuws/2011/as-of-1january-2012-new-income-requirements-highly-skilled-migrants-and-highly-educated-migrants.aspx)
} 
Table 7: The Dutch scheme for the orientation year for highly-educated persons, 2013

\begin{tabular}{|c|c|}
\hline & Maximum number of points \\
\hline \multicolumn{2}{|l|}{ Educational Attainment ( $\max 30$ points): } \\
\hline Master's Degree & 25 \\
\hline PhD Degree & 30 \\
\hline Age between 21 and 40 years (max 5 points) & 5 \\
\hline $\begin{array}{l}\text { Indicators for success in the Netherlands (max. } 5 \\
\text { points) }\end{array}$ & 5 \\
\hline
\end{tabular}

Pass mark 35

Source: NUFFIC (www.nuffic.nl) .The "Pass mark" denotes the number of points which are required for admission. Indicators for success in the Netherlands involve: previous employment in the country; previous education in the country; Dutch language proficiency, English language proficiency; Degree granted by a country that has signed up to the Bologna declaration.

In June 2011 the Netherlands has implemented the EU Blue Card initiative. Compared to the "knowledge migrant" scheme, the procedure to obtain the EU Blue Card is slower and more complicated. Moreover, the EU Blue Card involves both a salary requirement (EUR 61,469.28 gross) and an educational requirement (at least post-secondary degree). In the Highly Skilled Migrant Program only the threshold salary must be met, and the threshold is much lower. A decision on an EU Blue Card application may take up to 90 days. Differently from the knowledge migrant scheme, the EU blue card does offer though the opportunity to relocate to other EU member countries.

The Netherlands has also in place a tax incentive schemes to attract highly skilled immigrants. In particular, since 2001, Dutch employers can reimburse $30 \%$ of the taxable base of the employee's wages as a tax free reimbursement for extraterritorial expenses, for up to eight years since first entering the country.

\section{Italy}

Italy has a long history as a source of emigrants, and until 1986 immigration policy has been based on public order legislation dating back to 1931, which left many important issues to administrative discretion. In 1990 the so called "Martelli" law introduced a provision for a quota system to limit the inflow of immigrant workers from outside the EU, which did not target highly skilled workers. The quota system is mainly employer driven, and a labour market test requires the employer to list the job vacancy through the Public Employment Service. This provision is pro-forma though, as no application has ever been rejected due to a successful referral by the Public Employment System (Chaloff and Lamaitre 2009). Work visas are initially issued for a limited period (2 years in the presence of an open-ended contract), but they can be renewed and converted into a residence permit after five years of legal stay. 
The quota system grants a privileged access for citizens from countries which have signed an immigration agreement with the Italian government. Up to 52,080 workers from these countries are admitted to Italy according to the 2010-2011 legislation, and they will face no restriction as far as their sector of employment is concerned. The second category is represented by citizens of other countries with which Italy does not have an agreement on immigration. Up to 30,000 foreigners are admitted under this grouping, but they will be allowed to work only as domestic helpers or care workers. Up to 11,000 other permits will be issued to convert other visas (issued for study, training, seasonal work) to regular work permits. Altogether, until 2011 the Italian quota system, administered through the so called "Decreto Flussi" issued every year, did not consistently target highly skilled workers, and poor enforcement of the existing legal framework has lead to the introduction of multiple legalization programs over the years (see Casarico, Facchini and Frattini 2012).

A substantial change has been introduced by the reception in 2012 of the EU Blue Card initiative. Effective August 8, 2012, highly skilled non-EU citizens can be admitted outside of the quota system, provided that they have completed at least a three-year bachelor's degree relevant to the job for which they apply and have a binding employment contract in which they are offered a minimum salary above $€ 24.789,00 .{ }^{23}$ After 5 years of residence as a Blue Card holder (in any EU country, with at least 2 continuous years in Italy), a long-term EC resident permit can be issued.

The overall policy has become thus more oriented towards the admission of highly skilled foreign workers, but it seems to have been more the result of a EU wide initiative, that the end point of a process through which foreign talents have been seeked by domestic employers.

\section{Spain}

Like Italy, Spain has been for most of the past century a country of emigration (OECD, 2003a), and Spanish workers supplied much of the manpower recruited by Northern European countries' guest worker programs. In fact, between 1961 and 1974, about 100,000 Spanish workers emigrated every year. The fall of Franco's authoritarian regime, the entry of the country in the European Union, and the subsequent rapid growth experienced in the eighties and nineties have turned Spain in an attractive destination for foreign nationals, coming from both Latin America and North Africa.

The first piece of legislation introduced to regulate foreign immigrant flows, the Foreigners Law of 1985, was the result of Spain's need to align its policies to those of the EC bodies, rather than being a policy response to growing immigration pressure. According to this framework - known as the "general regime" -, the entry of a labour migrant was based on an employer request and the admission was left essentially to administrative discretion (Bruquetas-Callejo et al., 2008). A key discriminant was a labour market test whose criteria were only vaguely defined.

Along with the general regime, a new channel of entry was established in 1993 with the introduction of an immigration quota for which no individual labour market test had to be performed. The latter was replaced by the government's identification, on a yearly basis, of

\footnotetext{
${ }^{23}$ The minimum gross income for a foreign worker to qualify under the EU Blue Card initiative cannot fall below three times the threshold needed to be exempted from healthcare co-payments.
} 
those sectors/occupations with labour shortages and by its determination of the overall number of work permits to be issued. Importantly, the permits issued under the "contingent" system were not flexible, i.e. they typically did not allow migrants to change sector or region of employment, and the total yearly quota was kept very low, fluctuating between 20-40 thousand permits per year. The very strict official policy stance ended up favouring irregular immigration, that turned into a structural feature of the Spanish immigration regime.

The return of the Socialist party to power in 2005 marked the re-introduction of the general regime, with the purpose of allowing more flexibility for employers, even if the overall quota depended on an assessment of the labour market needs. To this end, a Special Catalogue of Vacant Jobs was created: under the general regime 120,324 initial work and residence permits were issued in 2006, 178,340 in 2007, and 136,604 in 2008 (IOM, 2010). Similarly to the Italian experience Spain entered also in a series of bilateral immigration agreements to facilitate and control the recruitment of workers in a series of countries of origin. Migrants from those countries receive priority in the allocation of work permits (IOM, 2010).

While the quota system could have been used to introduce selective immigration policies, its actual effects have been rather limited (Bruquetas-Callejo et al., 2008), because of a widespread lack of enforcement. The result has been the creation of large stocks of irregular migrants, which have periodically benefitted from large regularization programs. In other words, through much of the immigration boom years the official Spanish government policies have only played a very limited role in shaping the current composition of the immigrant population.

After the onset of the big recession migration to Spain virtually come to a halt. The number of work permits issued on the basis of the Special catalogue of Vacant Jobs - in the first nine months of 2009 the figure was down to only 15,000 (a drop by more than 80\% compared to the previous year). In 2011 the country has implemented the EU Blue Card initiative, but no figures are yet available concerning the number of skilled foreign workers admitted under this program. ${ }^{24}$

\section{Policies to attract highly skilled immigrants: evidence based on UN data}

The pattern towards the adoption of more skill-selective immigration policies is confirmed when we look at recent, comprehensive cross-country survey data. Since 1974 the United Nations asks government officials for their views on the overall level of immigration in their country and for information concerning the policies towards immigration they implement. An additional question was introduced in 2007, with a specific focus on governments' policies towards highly skilled workers, a sign of the growing interest around the globe in policies to attract highly skilled workers. Table 8, based on Facchini and Mayda (2010) reports the answer to this question, grouped by each country's income level.

\footnotetext{
24 In order to obtain the Blue Card, applicants must hold a university degree from an educational program that lasted three years or longer. Alternatively, they can prove their qualifications by showing at least five years of professional experience. Moreover, their employer must pay them at least 1.5 times the most recent average gross monthly wage in Spain, as determined by the Spainsh Statistical Office. The salary threshold may be reduced to 1.2 times the most recent average gross monthly wage in Spain for jobs which are in particular need of non-EU workers and which belong to ISCO groups 1 and 2.
} 


\begin{tabular}{lccccc} 
& \multicolumn{5}{c}{ Policy on highly skilled workers } \\
Income group & Lower & Maintain & Raise & No & Total \\
\hline High income countries & 2 & 18 & 20 & 5 & 45 \\
& 4.44 & 40 & 44.44 & 11.11 & 100 \\
Upper middle income countries & 1 & 24 & 9 & 2 & 36 \\
& 2.78 & 66.67 & 25 & 5.56 & 100 \\
Lower middle income countries & 2 & 29 & 4 & 2 & 37 \\
Low income countries & 5.41 & 78.38 & 10.81 & 5.41 & 100 \\
& 0 & 13 & 3 & 9 & 25 \\
All countries & 0 & 52 & 12 & 36 & 100 \\
& 5 & 84 & 36 & 18 & 143 \\
\hline \hline
\end{tabular}

Source: Facchini and Mayda (2010). The table presents frequencies and row percentages by income, size of migration inflow and size of migration rate. Policy on highly skilled workers is the government's policy on the migration of highly skilled workers. The possible values of Policy on highly skilled workers are: The government has policies in place to lower, maintain, raise the migration of highly skilled workers, the government does not intervene with regard to the migration of highly skilled workers (or it is not known whether the government intervenes...). Data for migration is for 2005. The migration rate is defined as the migration inflow divided by the population of the destination country.

Officials in only five destinations (Bhutan, Botswana, Jordan, Saudi Arabia and the United Arab Emirates) reported in 2007 to have policies in place to reduce the arrival of highly skilled workers. Most of the countries in the sample (59 per cent) state instead that the government's goal is to retain the same level of high-skilled migration, and this kind of attitude is particularly widespread among low and middle-income countries. A race to attract global talents appears to have started, on the other hand, among the high income countries considered in the study. Almost half of the officials based in them (44.4\%) report to have now policies in place to increase the arrival of highly skilled foreign workers. Understanding the implications of these policies for for both destination and source countries is one of the important challenges faced by researchers working on migration today.

\section{$7 \quad$ Conclusions}

In this paper we have reviewed the policies put in place by the main Western destination countries to attract highly skilled migrants. We have identified two broad sets of instruments. On the one hand, employer-driven schemes typically require the migrant to meet a set of minimum skill requirements and, crucially, to have a job offer before a work visa can be issued. On the other, employee-driven schemes typically do not require a job offer, and instead lead to the identification of the migrant to be admitted on the basis of a set of characteristics chosen by the policy maker.

While many countries have in place complex migration policy systems with features of both employer- and employee-driven schemes, three traditional destinations have made the latter a prominent feature of their policies: Australia, Canada and New Zealand. Most other countries, including the United States, are using instead employer driven systems. 
Even if selection on the basis of skill requirements involves only a small portion of the total number of migrants admitted by Western destination countries, there is some evidence suggesting that employee-driven schemes have had some success in increasing the skill level of the average migrant (Aydemir and Borjas 2007, Aydemir 2011).

The evidence on employer-driven schemes is less clear cut. On the one hand, in the case of countries that host large numbers of foreign students, these systems have enabled the recruitment of the highly talented and motivated foreigners most advanced countries are competing for. The U.S. H1-B scheme is a leading example, and recent research has highlighted the important role played by foreign immigrants admitted through this program in fostering innovation activity in the U.S. (Kerr and Lincoln 2010). As for other destinations that have been traditionally less successful in attracting foreign students, such as many of the continental European countries, the employer-driven model has shown important limits. The limited success of the German Green Card program of the early 2000s has highlighted in particular the difficulties of requiring an employment contract as a prerequisite for a work visa if the perspective employee has limited or no-experience of the destination country.

Some interesting new policy initiatives have been introduced to deal with this important shortcoming of employer-driven systems. Particularly promising in our opinion is the Dutch scheme for the orientation year of highly-educated persons, which allows recent foreign graduates to come to the country to look for a highly skilled occupation, even if it is still too early to assess its impact.

More time is also needed to evaluate the effectiveness of other attempts to improve employerdriven schemes - like the EU Blue Card initiative. Some scepticism is warranted. While the measure was introduced to make the EU more attractive to skilled migrants by opening up the entire EU labour market, the implementation of this initiative by each member state has led to multiple practical obstacles to the relocation of third country nationals. In fact, even after the conclusion of the required initial 18 months period of permanence in a EU country, a skilled worker who wants to move to another member still has to go through a complex bureaucratic process, in which the migration authorities of the new destination have ample discretionary power in the issuance of the permit. As a result, access to the broader EU labour market, beyond the initial country is likely to remain rather limited.

\section{References}

Aydemir, A. (2011) "Immigrant selection and short-term labor market outcomes by visa category" Journal of Population Economics 24:451-475

Aydemir, A., Borjas, G. J., (2007), "Cross-Country Variation in the Impact of International Migration: Canada, Mexico, and the United States," Journal of the European Economic Association, 5: 663-708.

Beach C., Green, A.G., Worswick, C., (2007), "Impacts of the Point System and Immigration Policy Levers on Skill Characteristics of Canadian Immigrants", in Barry R. Chiswick (ed.) Immigration (Research in Labor Economics, Volume 27), 349-401. 
Bruquetas-Callejo, M., Garces-Mascarenas, B., Moren-Alegret, R., Penninx, R., RuizVieytez, E., (2008), "Immigration and integration policy making in Spain.", IMISCOE Working Paper No. 21.

Casarico A., Facchini, G., and T. Frattini (2012), "What drives immigration amnesties?" CES-Ifo WP 3981

Chaloff, J. And G. Lemaitre (2009), "Managing highly skilled labour migration: A comparative analysis of migration policies and challenges in OECD countries." OECD Social, Employment and Migration Working Paper No. 79.

Citizenship and Immigration Canada (2008) "Facts and figures: Immigration Overview." Ottawa: CIC.

Congressional Research Service (2006), "H1B visas: legislative history, trends over time and pathways to permanent residence." Mimeo, Washington DC: US Congress.

Constant, A. and B. Tien, (2011), “Germany's Immigration Policy and Labor Shortages", IZA DP 41.

European Commission (2005), Communication from the Commission - Policy Plan on Legal Migration, COM 2005, 0669, Brussels.

European Commission (2004), Green Paper on an EU approach to managing economic migration, EC COM 2004/0811, Brussels.

European Council (2009), Council Directive 2009/50/EC of 25 May 2009 on the conditions of entry and residence of third-country nationals for the purposes of highly qualified employment, Brussels.

European Council (2005), Council Directive 2005/71/EC of 12 October 2005 on a specific procedure for admitting third-country nationals for the purposes of scientific research, Brussels.

European Council (2004) Council Directive 2004/114/EC of 13 December 2004 on the conditions of admission of third-country nationals for the purposes of studies, pupil exchange, unremunerated training or voluntary service, Brussels.

Facchini, G. and A.M. Mayda (2010) "What drives immigration policy? Evidence from a survey of government officials", in I. Gang and G. S. Epstein (eds) Culture and Migration Frontiers of Economics and Globalization, Volume X, World Scientific, pages 605-648

Facchini, G., A.M. Mayda and P. Mishra (2011), "Do interest groups affect US immigration policy?," Journal of International Economics, 85:114-128.

Glied, S., Sarkar, D., (2009), "The role of professional societies in regulating entry of skilled immigrants: The American Medical Association." in Skilled migration: Problems, Prospects, and Policies, J. Bhagwati and G. H. Hanson (eds.), Oxford and New York: Oxford University Press, Oxford and New York, 184-206. 
Green, A.G., Green, D.A., (1999), “The Economic Goals of Canada's Immigration Policy, Past and Present." Canadian Public Policy 25: 425-451.

Hansen, R., (1999), "The Politics of Citizenship in 1940s Britain: The British Nationality Act" Twentieth Century British History 10: 67-95.

Holzmann, R., Koettl J., Chernetsky T. (2005), "Portability regimes of pensions and health care benefits for international migrants: An analysis of issues and good practices" mimeo, The Global Commission on International Migration.

IOM (2010), "Migration and the Economic Crisis in the European Union: Implications for Policy", Geneva.

Kerr W. R and W.F. Lincoln (2010) "The supply side of innovation: H1-B visas reforms and US ethnic invention“"Journal of Labor Economics 28: 473-508.

Kleven, H.J., C. Landais, E. Saez and E.A. Schultz (2012) "Taxation and International Migration of Top Earners: Evidence from the Foreigner Tax Scheme in Denmark", forthcoming, Quarterly Journal of Economics.

Laubenthal, B., (2012),"Labour migration governance in contemporary Europe. The case of Germany”, LAB-MIG-GOV Country Report..

Liebig, T., (2007), "The labour market integration of immigrants in Denmark", OECD Social, Employment and Migration Working Papers no.50.

Linacre, S., (2007), "Migration: permanent additions to Australia's population." Canberra: Australian Bureau of Statistics.

McHale, J., Rogers, K., (2009) "Selecting economic immigrants: A statistical approach" WP 0145, National University of Ireland.

Migration Advisory Committee (2012) "Limits on Migration“, Home Office

National Contact Point, The Netherlands (2005), "A review of recent literature on the impact of immigration on Dutch society", in Berlin Institute for Comparative Social Research (eds.), The Impact of Immigration on Europe's Society: A Pilot Research Study undertaken by the European Migration Network, Berlin: BIVS.

NZ Parliamentary Library (2008), "Immigration chronology: selected events 1840-2008", Parliamentary Library Research Paper 2008/01, Wellington: Author.

OECD (2003a), Spain: Economic Survey. Paris: OECD.

OECD (2003b), New Zealand: Economic Survey. Paris: OECD.

Phillips, J. and H. Spinks (2012), "Skilled migration: temporary and permanent flows to Australia”, Background note, Parliamentary Library, Canberra. 
Profit, F., Gelleni, C., Zamorano, E., (2008), "Migration and Education: Quality Assurance and Mutual Recognition of Qualifications - Case Study France", Paris: UNESCO.

Sommerville, W., D. Srinskandarajah and M. Latorre "United Kingdom: A Reluctant Country of Immigration", Migration Policy Institute, available at http://www.migrationinformation.org/feature/display.cfm?ID=736

Sopemi (2011), "Rapport du Sopemi pour la France : Immigration et presence Etranger en France en 2010", Paris : OECD.

Winkelmann, R., (1999), "Immigration: The New Zealand Experience," IZA Discussion Papers 61.

Zimmermann, K.F., (1995), "Tackling the European Migration Problem." Journal of Economic Perspectives 9, 45-62. 